\title{
Hubungan Hukum antara Pemerintah dengan Badan Usaha Swasta dalam Berbagai Pola Kontrak Kerjasama Pengusahaan Pertambangan
}

\author{
Abrar Saleng
}

\begin{abstract}
In a welfare state, the administration of non-goveming functions requires that there have been an equal relation between the legal subjects. The relations probably arise from various legal civil actions taken by the government bodies, particularly those bodies with status of legal entity. The civil legal between the government with civil of legal entity are directed at achieving the highest welfare of the community. The pattem of cooperation contract based on the mining exploitation in juncture of foreign investment according to the meaning and substance of the rights of the state control shall be production sharing contract.
\end{abstract}

\section{Pendahuluan}

Secara konseptual Hak Penguasaan Negara dalam lingkup mengurus (besturen) atas bahan galian (bahan tambang) yang tergolong strategis merupakan monopoli negara. Hak monopoli tersebut dengan cara apapun tidak dapat dialihkan dan didelegasikan hak penguasaanya kepada pihak swasta manapun untuk mengatur pengusahaannya. Pertanyaan: "Bagaimanakah dengan kontrak kerjasama (berupa: kontrak karya dan kontrak Production sharing) dengan pihak asing? Kontrak karya Pertambangan dan kontrak Production sharing bukanlah suatu mekanisme pengalihan hak penguasaan negara, tetapi merupakan suatu sarana atau instrumen hukum yang memungkinkan pihak swasta asing untuk dapat turut serta di dalam usaha pertambangan.

Oleh karena itu untuk menyikapi fenomenafenomena di atas, sudah saatnya diciptakan kesungguhan semua pihak yang terkait, terutama pemerintah dalam melakukan pengaturan pengusahaan bahan galian yang dikembalikan kepada semangat dan jiwa Pasal 33 UUD 1945 dengan pertimbangan; karakteristik usaha pertambangan, efisiensi dan efektifitas secara ekonomi serta berkeadilan sosial bagi seluruh rakyat Indonesia.

Pengusahaan bahan galian dalam konteks hak penguasaan negara menjadi dilematis. 
Di satu sisi hak penguasaan tidak dapat dialihkan dan didelegasikan kepada pihak swasta asing. Di sisi lain negara tidak mempunyai kemampuan untuk mengusahakan sendiri bahan galian agar bermanfaat bagi kesejahteraan rakyat. Karena itu negara membangun relasi dengan sektor swasta asing. Hubungan yang demikian selanjutnya berkembang dan melahirkan suatu pranata hukum berupa perikatan khusus. Dikatakan khusus karena perikatan tersebut berlangsung antara negara (publik) di satu pihak dengan sektor non-publik di pihak lain. Di sini perlu dicermati sejauhmanakah pengembangan hukum perikatan yang bersumber dari Pasal 33 UUD 1945 yang di dalamnya kondusif agar cabang-cabang produksi dan sumber daya alam dikelola demi sebesar-besarnya kemakmuran rakyat.

\section{Hubungan Hukum antara Negara dengan Pihak Swasta dalam Usaha Pertambangan}

Secara teoritis, terdapat dua konstruksi yuridis yang digunakan dalam menelaah hubungan hukum antara Negara/Pemerintah dengan badan hukum/perorangan baik sebagai pemegang kuasa pertambangan maupun sebagai kontraktor dalam kontrak kerjasama yaitu; (1) hubungan hukum antara pemerintah dengan badan hukum/perorangan yang didasarkan pada status pemerintah sebagai pemegang wewenang atributif dan hak istimewa (eksklusif); (2) hubungan antara pemerintah dan badan hukum/perorangan berdasarkan hubungan kontraktual.

\section{(1) Hubungan Hukum Didasarkan pada Status Pemerintah sebagai Pelaksana Hak Penguasaan Negara}

Inti hubungan yang mengandalkan status menurut Parson adalah power and priveleges ${ }^{\prime}$ Kedua hal tersebut menunjukkan supremasi secara struktural. Di masyarakat tradisional kedua hal itu dapat dicermati di dalam struktur kekerabatan. Hubungan yang berlangsung di sana bukan karena konsensus subjek individual, tetapi berdasarkan kerangka normatif struktur sosial yang ada. Di level negara kerangka hubungan yang demikian menurut Colin Turpin," "invested by law" Hal senada juga dikemukakan oleh Antony Allot, bahwa pre-eminent cases of category (status relationship) is provide by the legally recognized, defined and protected status. ${ }^{3}$ Sementara itu, menurut Friedmann, ${ }^{4}$ pola hubungan yang didasarkan status, meskipun hingga kini dipraktikkan negara modem, tetapi hal tersebut sangat selektif. Hal ini terjadi karena pendasaran ontologis dalam hubungan status adalah situasi masyarakat abad pertengahan yang sederhana, relegius dan etatis. Adapun negara modern sudah menunjukkani ciri yang berbeda yakni lebih demokratis, kompleks dan rasionil.

'Terkutip dalam Deno Kamelus. 1998. "Fungsi Hukum Terhadap Ekonomi di Indonesia. " Disertasi PPs. Surabaya: UNAIR. HIm. 326.

${ }^{2}$ Colin Turpin. 1972. Government Contract. London: Penguin Book Ringwood. Hlm. 23.

${ }^{3}$ Terkutif dalam Deno Kamelus. Loc. Cit.

4W. Friedmann. 1960. Legal Theory. London: Stevens \& Sons. HIm. 165. 
Berdasarkan konstruksi hukum yang demikian, maka Pemerintah dalam statusnya sebagai pelaksana hak penguasaan negara dan pengaturan pengusahaan bahan galian, sifatnya atribusi. Dengan demikian, seyogyanya hubungan hukum yang timbul berdasarkan kewenangan atributif lebih didasarkan pada status pemerintah selaku pemegang hak istimewa. Status yang demikian, kalaupun didelegasikan atau dimandatkan kepada pihak swasta (pemegang kuasa pertambangan dan/atau kontraktor), kedudukannya sebagai subordinasi terhadap pemerintah.

\section{(2) Hubungan antara Pemerintah dan Kontraktor Merupakan Hubungan Kontraktual}

Inti hubungan kontraktual menurut Parsons adalah "free agreement of individuals ${ }^{{ }^{5}}$ Motivasi yang fundamental mengenai beralihnya suatu pola hubungan dari status ke kontraktual adalah hasrat untuk maju dan lebih rasionil sesuai dengan tuntutan perkembangan ekonomi dan hubungan industrial.

Segi-segi hubungan yang bersifat kontraktual tersebut diperkenalkan oleh UU PMA dalam bentuk kontrak karya. ${ }^{6}$ Meskipun sudah ada petunjuk yang mengarah ke bentuk hubungan yang sifatnya kontraktual antara pemerintah dengan kọntraktor, tetapi hal tersebut belum dilandasi oleh suatu pengkajian secara filosofis dan teoritis yuridis. Padahal kebutuhan tersebut sudah mendesak. Karena itu, perlu dikajiulang secara mendalam beberapa hal penting dalam kerangka hubungan kontraktual antara lain;

(a) hakikat dasar hubungan antara pemerintah dan kontraktor dalam kerangka hak penguasaan negara menurut Pasal 33 UUD 1945;

(b) tujuan swastanisasi;

(c) sejauhmana peranan dan tanggung jawab kontraktor untuk mensejahterakan rakyat;

(d) bentuk hubungan hukum atau kejasama antara pemerintah dengan kontraktor berdasarkan Pasal 33 UUD 1945;

(e) kedudukan masyarakat luas dalam kerangka hubungan kontraktual;

(f) mekanisme penyelesaian sengketa apabila terjadi perbedaan interpretasi mengenai kepentingan umum;

(g) subjek yang ditugasi negara untuk melakukan kontrak.

Dengan referensi tersebut di atas, maka baru dapat diformulasikan pola hubungan kontraktual yang paling sesuai dengan makna Hak Penguasaan Negara (HPN) atas Pertambangan berdasarkan UUD 1945.

Selama ini, HPN dalam lingkup mengurus (mengusahakan) sendiri bahan galian melalui Perusahaan Negara, BUMN dan BUMD, belum menunjukkan peran yang optimal. Kekurangan modal, penguasaan teknologi, dan ketidakmampuan dalam manajemen,

${ }^{5}$ Terkutif dalam Deno Kamelus. Op. Cit. Hilm. 328.

${ }^{6} \mathrm{Pasal} 8$ ayat (1) berbunyi: "Penanaman modal asing di bidang pertambangan didasarkan pada suatu kerjasama dengan Pemerintah atas dasar kontrak karya atau bentuk lain sesuai dengan peraturan perundangundangan yang berlaku". 
selama ini dijadikan alasan bagi negara untuk menguasakan pengusahaan bahan galian kepada pihak swasta asing melalui kontrak kerjasama.

Alasan-alasan tersebut di atas dipandang terlalu dogmatis atau dicari-cari untuk membenarkan keserakahan pihak swasta. ${ }^{7}$ Sebab di sisi lain uang bank-bank Pemerintah dihambur-hamburkan antara lain melalui bantuan rekapitalisasi terhadap bank-bank tertentu sampai menjadi kredit macet. Demikian pula alasan kemampuan teknologi, tentu saja tidak selalu lebih canggih dari teknologi industri dirgantara yang konon sudah dikuasai putra-putri Indonesia. Ditinjau dari bagaimana mengeksploitasi bahan galian yang paling maksimal dan ideal adalah negara sendiri yang mengusahakannya, sehingga seluruh hasil produksinya merupakan pendapatan negara dan pemanfaatannya untuk sebesar-besamya kemakmuran rakyat. Namun dalam pelaksanaannya tidaklah demikian, sebab masih ada ruang dan tempat bagi usaha swasta untuk melakukan usaha pertambangan.

\section{Pola-pola Kontrak Kerjasama dalam Usaha Pertambangan}

Usaha pertambangan berdasarkan kontrak kerjasama antara Pemerintah dengan pihak Swasta asing melalui penanaman modal asing dikenal berbagai pola yaitu; kontrak karya (contract of work) untuk sektor pertambangan umum ${ }^{8}$ dan Kontrak Production Sharing (Production Sharing. Contract) untuk sektor pertambangan Migas. Selain kontrak karya Pertambangan dan kontrak production sharing, dikenal juga pola kerjasama dalam subsektor pertambangan batubara yang dikenal Perjanjian Karya Pengusahaan Pertambangan Batubara. Pola lain dalam pengusahaan pertambangan adalah kerjasama BUMN selaku pemegang kuasa pertambangan dengan pihak swasta asing yang melakukan kontrak karya Pertambangan.

\section{(1) Kontrak Karya Pertambangan (Mining Contract of Work)}

Sebelum diuraikan pengertian kontrak karya pertambangan, terlebih dahulu diuraikan pengertian kontrak itu sendiri. Kontrak (contract, contracten) disebut juga perjanjian. Menurut Subekti, ${ }^{9}$ pengertian kontrak lebih sempit dari perjanjian karena kontrak mensyaratkan bentuknya selalu tertulis, sedangkan perjanjian bentuknya selain tertulis dapat juga dilakukan secara lisan. Apabila demikian pengertian kontrak, maka hukum kontrak merupakan specis dari hukum perjanjian. Salah satu asas dalam hukum perjanjian bahwa berbagai kaidah hukum yang mengatur soal kontrak di dalam peraturan perundang-undangan merupakan hukum pelengkap (aanvullend recht). Berdasarkan asas tersebut, maka kaidah hukum perjanjian dapat dipersempit atau diperluas oleh para pihak yang membuat perjanjian/kontrak. ${ }^{10}$

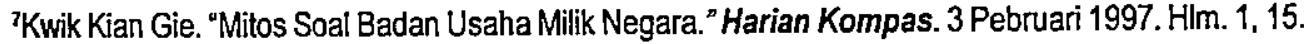
¿Lihat Pasal 8 ayat (1) UUPMA dan Pasal 10 ayat (1) UUPP 1967.

${ }^{9}$ R. Subekti. 1983. Pokok-pokok Hukum Perjanjian. Jakarta: Intermasa. HIm. 1.

${ }^{10} \mathrm{R}$. Subekti. 1984. Pokok-pokok Hukum Perdata. Jakarta: Intermasa. HIm. 142.
} 
Hukum kontrak secara berkelanjutan berkembang terus. Subjek yang tersangkut di dalamnya tidak terbatas pada manusia individual saja, tetapi lebih luas lagi seperti badan hukum dan negara. Substansinyapun semakin kompleks. Pernyataan kehendak (promise) dan konsensus saja tidak cukup, tetapi perlu unsur-unsur lain seperti isi kontrak tidak boleh bertentangan dengan hukum, moral, kepatutan dan kesusilaan.

Dalam Pasal 1320 KUHPerdata mensyaratkan sahnya suatu perjanjian adalah; (a) sepakat mereka yang mengikatkan diri; (b) kecakapan untuk membuat suatu perikatan; (c) sesuatu hal tertentu; (d) suatu sebab yang halal. Khusus dalam kontrak karya pertambangan, selain isi, juga ditentukan mengenai hal-hal yang bersifat formal seperti berbagai persyaratan yang harus tercantum di dalamnya yang dituangkan dalam bentuk tertentu dan persyaratan formal lainnya seperti persyaratan teknis dan finansial.

\section{a. Pengertian dan Dasar Hukum}

Secara terminologi pengertian kontrak karya adalah kontrak antara pemerintah Republik Indonesia dengan Perusahaan Penanaman Modal Asing (berbentuk badan hukum Indonesia dan berkedudukan di indonesia) yang memuat persyaratan teknis, finansial dan persyaratan lain untuk melakukan usaha pertambangan bahan galian di Indonesia, kecuali minyak dan gas bumi, batu bara dan uranium.

Dasar hukum pola kontrak karya pengusahaan pertambangan terdapat dalam Pasal 8 ayat (1) Undang Undang Nomor 1 Tahun 1967 tentang Penanaman Modal Asing (PMA), dan Pasal 10 ayat (1) dan (3) UUPP 1967 dengan istilah perjanjian karya. Kedua ketentuan tersebut, merupakan dasar hukum kontrak karya dan bentuk-bentuk kontrak kerjasama lainnya, karena kedua ketentuan itu memungkinkan keterlibatan investor asing dalam usaha pertambangan di Indonesia. Digunakannya pola kontrak karya dalam pengusahaan pertambangan di Indonesia menurut Soetaryo Sigit, ${ }^{11}$ diilhami oleh rumusan Pasal 5a Indische Mijnwet 1899. Dalam perkembangan dan pelaksanaannya, kontrak karya memuat ketentuan-ketentuan yang lebih lengkap dan menyeluruh dibandingkan dengan " $5 a$ Contract", ${ }^{12}$ pada jaman Belanda. Kelebihan itu, antara lain kontrak karya memberikan hak sekaligus kepada kontraktor untuk melaksanakan usahanya sejak dari tahap penyelidikan umum (survei), eksplorasi sampai dengan eksploitasi, pengolahan dan penjualan hasil produksi tanpa ada pemisahan antara tahap praproduksi dengan operasi-produksi. ${ }^{13}$

"Soetaryo Sigit. 1996. "Potensi Sumber Daya Mineral dan Kebangkitan Pertambangan Indonesia." Pidato Ilmiah pada Penganugrahan Gelar Doktor Honoris Causa. Bandung: ITB. HIm. 36.

${ }^{12}$ Disebut 5 a Contract, karena kontrak kerjasama usaha pertambangan ini dibuat berdasarkan Pasal $5 \mathrm{a}$ Indische Minjwet 1899.

"Tidak sama dengan usaha pertambangan dengan pemberian Kuasa Pertambangan yang pemberiannya disesuaikan dengan tahap atau jenis usaha pertambangan yang diusahakan. 
Dalam naskah kontrak karya dimuat ketentuan-ketentuan yang mengatur soal-soal yang mencakup; aspek hukum, teknis, kewajiban di bidang keuangan dan perpajakan, ketenagakerjaan, perlindungan dan pengolahan lingkungan, hak-hak khusus pemerintah, penyelesaian sengketa, pengakhiran kontrak, soal-soal umum (antara lain; promosi kepentingan nasional, pengembangan wilayah) dan ketentuanketentuan lain. Semua ketentuan-ketentuan itu diberlakukan selama jangka waktu kontrak.

Kemudian yang sangat menarik ialah pemerintah memberikan perlakuan khusus atau lex specialis terhadap kontrak karya pertambangan. Perlakuan khusus artinya segala ketentuan-ketentuan atau kesepakatan yang telah tercantum dalam kontrak, tidak akan pernah berubah karena terjadinya peraturan perundang-undangan yang berlaku umum (lex generali). Kalaupun akan diubah (renegoisasi), maka terlebih dahulu harus ada kesepakatan para pihak. ${ }^{14}$

Perlakuan khusus yang demikian merupakan jaminan kepastian hukum bagi investor. Kepastian hukum penting, sebab boleh jadi ketiadaan jaminan seperti itu, merupakan sumber yang potensial dari berbagai macam pungutan, korupsi dan kolusi yang pada akhirnya akan mengakibatkan keengganan investor asing menanamkan modalnya di sektor pertambangan.

\section{b. Para Pihak dalam Kontrak Karya}

Dalam Pasal 10 ayat (1) menyebutkan sebagai berikut;

"Menteri dapat menunjuk pihak lain sebagai kontraktor apabila diperlukan untuk melaksanakan pekerjaan-pekerjaan yang belum atau tidak dapat dilaksanakan sendiri oleh Instansi Pemerintah atau Perusahaan Negara yang bersangkutan sebagai pemegang kuasa pertambangan".

Ketentuan tersebut jelas bahwa Menteri hanya dapat menunjuk kontraktor yang bekerja untuk instansi Pemerintah atau Perusahaan Negara selaku pemegang kuasa pertambangan. Apabila dicermati ketentuan tersebut terdapat kerancuan, sebab pemegang kuasa pertambangan dapat melakukan kontrak dengan pihak lain sebagai kontraktor, tetapi yang menunjuk adalah Menteri selaku pemberi kuasa pertambangan. Dengan kata lain yang akan membuat kontrak adalah instansi pemerintah dan perusahaan negara (pemegang kuasa pertambangan), tetapi yang menunjuk pihak sebagai lawan kontraknya adalah pihak lain (Menteri). Kontraktor di sini bekerja untuk instansi pemerintah dan/atau pemegang kuasa pertambangan. Selain kerancuan itu, penggunaan istilah dalam Pasal 10 di atas, juga tidak konsisten antara istilah kontraktor (ayat (1)) dengan istilah

${ }^{14}$ Sebagai ilustrasi ialah kasus Dugaan Korupsi, Kolusi dan Nepotisme (KKN) pada proses perpanjangan Kontrak karya PT. Freeport Indonesia (PT FI). Meskipun kasus ini kelak dibuktikan adanya KKN, Pemerintah tidak dapat membatalkan kontrak karya secara sepihak, melainkan harus duduk bersama (Pemerintah dan kontraktor) merundingkan kembali (renegosiasi) berbagai hal yang dianggap merugikan negara dalam rangka membuat kesepakatan baru yang lebih proporsional. 
perjanjian karya (ayat (2) dan (3)). Melihat kedua dasar hukum pola kontrak karya pertambangan, seolah-olah terdapat pertentangan satu sama lain atau terdapat dualisme mengenai siapa yang bertindak sebagai prinsipal dalam kontrak karya. Dari pertentangan itu muncul pertanyaan: "Siapakah yang berwenang mewakili negara dalam melakukan kontrak karya pertambangan (instansi pemerintah atau perusahaan negara atau pemerintah?). Untuk menjawab pertanyaan ini perlu ditelusuri ketentuan perundang-undangan yang terkait.

\section{(1) Menurut UUPP 1967}

(a) Ketentuan Pasal 10 ayat (1) UUPP 1967 berbunyi;

"Menteri dapat menunjuk pihak lain sebagai kontraktor....untuk instansi pemerintah atau perusahaan negara..... sebagai pemegang kuasa pertam-bangan"

Instansi pemerintah yang dimaksud dalam ketentuan di atas adalah instansi pemerintah di bawah Menteri Pertambangan dan Energi. Pengertian instansi pemerintah jelas berbeda dengan Pemerintah. Pemerintah pusat atau disebut Pemerintah ialah perangkat Negara kesatuan Republik Indonesia yang terdiri atas Presiden beserta pembantu-pembantunya. Sementara instansi pemerintah adalah badan pemerintahan umum seperti jawatan, kantor. ${ }^{15}$

(b) Pasal 5 butir a jo Pasal 6 UUPP 1967 berbunyi;
"Usaha pertambangan dapat dilaksanakan oleh;

a: Instansi Pemerintah yang ditunjuk oleh Menteri;

b. Perusahaan Negara; dan seterusnya"

Ketentuan di atas juga menyebut secara tegas bahwa usaha pertambangan dapat dilakukan oleh Instansi Pemerintah dan Perusahaan negara, tetapi bukan Pemerintah.

(c) Penjelasan umum UUPP 1967 bagian penjelasan pokok-pokok persoalan angka 3 huruf a dan b menyebutkan;

"Dalam memanfaatkan kekayaan alam dapat diambil cara-cara pengusahaannya seperti berikut;

a. dikerjakan langsung oleh suatu instansi Pemerintah, penguasaan oleh instansi Pemerintah itu terutama ditujukan untuk penyelidikan umum dan eksplorasi sebagai usaha inventarisasi kekayaan alam Indonesia dan tidak dalam arti pengusahaan untuk mencari keuntungan, karena usaha pertambangan untuk mencari keuntungan tersebut seyogyanya diserahkan kepada Perusahaan Tambang Negara atau swasta. Begitupun bahan radioaktif perlu diusahakan oleh instansi Pemerintah dan dalam hal ini adalah Badan Tenaga Atom Nasional.

b. diusahakan oleh Perusahaan Negara"

15Departemen P dan K. 1995. Kamus Besar Bahasa Indonesia (edisi kedua). Jakarta: Balai Pustaka. HIm. 382. 
Bertolak dari berbagai ketentuan di atas, dapat disimpulkan bahwa yang bisa melakukan kegiatan pertambangan, baik penyelidikan umum dan eksplorasi sebagai usaha inventarisasi kekayaan alam, maupun usaha pertambangan lainnya adalah instansi pemerintah di bawah Menteri Pertambangan dan Energi (antara lain; Direktorat Geologi dan Lingkungan, PPTM dan Lemigas). Pemerintah hanya berwenang untuk menunjuk kontraktor bagi instansi Pemerintah dan sebagai pemberi Kuasa Pertambangan kepada Perusahaan Negara dan perusahaan swasta/Perorangan.

Apabila instansi pemerintah dalam ketentuan-ketentuan tersebut, dipahami sebagai Pemerintah (baca: Presiden beserta pembantu-pembantunya), secara hirarkhis tidak mungkin, karena Menteri itu sendiri adalah pembantu Presiden (Pasal 17 UUD 1945).

\section{(2) Menurut Undang-undang Nomor 1 Tahun 1967}

Pasal 8 ayat (1) Undang-undnag Nomor/ Tahun 1967menegaskan bahwa, PMA di bidang pertambangan didasarkan pada suatu kerjasama dengan Pemerintah atas dasar kontrak karya: Dari penegasan itu terkandung makna bahwa salah satu pihak dalam kontrak karya pertambangan adalah Pemerintah.

Berdasarkan ketentuan-ketentuan di atas dan pelaksanaannya, pola kontrak karya pertambangan mengikuti ketentuan yang ada dalam Undang-Undang Nomor 1 Tahun 1967 yaitu yang mewakili negara dalam membuat kontrak karya adalah Pemerintah dalam praktiknya oleh Menteri Pertambangan dan Energi atas nama Pemerintah.

Oleh karena kedua undang-undang ini, disebut sebagai dasar hukum pola kontrak karya pertambangan; namun terdapat perbedaan-perbedaan sebagaimana diuraikan di atas. Apabila terdapat dua ketentuan yang berbeda atau bertentangan dari produk hukum yang sederajat, maka dalam ilmu hukum sebagai solusi konfliknya digunakan asas hukum "lex specialis derogat legi generali" (aturan khusus mengkesampingkan aturan umum). ${ }^{16}$ Pertanyaan: "UU yang manakah dari kedua undang-undang tersebut sebagai lex specialis-nya?

Jika lex specialis-nya adalah UUPP 1967, maka pola yang digunakan adalah perjanjian karya dan Instansi Pemerintah atau Perusahaan Negara bertindak sebagai prinsipal, tetapi jika Undang-Undang Nomor 1 Tahun 1967 lex specilis-nya, maka yang digunakan adalah pola kontrak karya dengan Pemerintah bertindak sebagai principalnya.

Untuk menentukan undang-undang mana yang lex specialis terhadap yang lainnya, digunakan dua dasar argumentasi. Pertama, jika didasarkan pada pengaturan pengusahaan pertambangan pada umumnya (lex generali), maka pengusahaan pertambangan dengan pola kontrak karya merupakan lex specialis, terhadap pola lainnya seperti pola Kontrak Production Sharing, pola Perjanjian Kerjasama Pengusahaan Pertambangan Batubara dan Kerjasama

${ }^{16}$ Syarat /ex specialis adalah; (a) Peraturan Perundang-undangan yang tingkat hukumnya harus sama; (b) Peraturan perundang-undangan harus dalam rezim yang sama; (c) PerUU-an tidak mengenai objek yang khusus. 
BUMN dengan BUMS serta berdasarkan Kuasa Pertambangan. Karena kontrak karya merupakan pola khusus dalam kerjasama pihak asing dalam pengusahaan pertambangan dan kekhususan inilah yang menjadikan ketentuan Pasal 8. Undang-Undang Nomor 1 Tahun 1967 lex specialis terhadap ketentuan Pasal 10 ayat (1) UUPP 1967. Kedua, namun jika didasarkan pada bidang yang diaturnya, dimana Undang-Undang Nomor 1 Tahun 1967 dianggap sebagai undang-undang PMA pada umumnya (lex generali) dan UUPP 1967 yang mengatur khusus pertambangan merupakan lex specialis terhadap PMA di bidang lainnya seperti industri, perdagangan, dan pekerjaan umum. Karena kekhususan itu menjadikan UUPP 1967 lex specialis terhadap Undang-undang Nomor 1 Tahun 1967.

Dalam praktik pelaksanaannya sesuai dengan dasar argumentasi pertama di atas, yaitu pola kontrak karya dengan Pemerintah berindak sebagai prinsipal. Dengan demikian para pihak dalam kontrak karya adalah; (1) Pemerintah Republik Indonesia (diwakili Menteri Pertambangan dan Energi); dan (2) Perusahaan swasta asing atau perusahaan patungan antara perusahaan swasta nasional dan perusahaan swasta asing yang berbadan hukum Indonesia, disebut sebagai kontraktor.

\section{c. Status Hukum Pemerintah Dalam Kontrak Karya}

Dalam rangka mewujudkan kesejahteraan umum dan sebesar-besar kemakmuran dan keadilan sosial bagi seluruh rakyat, pemerintah turut menyelenggarakan berbagai fungsi di luar fungsi penyelenggaraan pemerintahan. Fungsi-fungsi baru yang tidak bersifat pemerintahan, menuntut pemerintah turut serta dalam pergaulan kemasyarakatan atau hubungan (hukum) sebagai pihak atau subjek yang tidak berbeda dengan subjek hukum perorangan atau badan-badan hukum keperdataan pada umumnya.Tindakan yang demikian menurut Bagir Manan ${ }^{17}$ adalah hubungan (hukum) kesederajatan yang merupakan hubungan keperdataan antara pemerintah dan orang atau badan hukum keperdataan. Hubungan keperdataan timbul dari perbuatan keperdataan misalnya melakukan kontrak dengan subjek hukum lainnya. Sedangkan yang dapat melakukan hubungan atau perbuatan perdata adalah badan hukum (rechtspersoon) atau manusia (natuurijkpersoon). Berdasarkan pemahaman ini, maka perbuatan hukum keperdataan pemerintah hanya dapat dilakukan oleh badan pemerintahan yang berstatus badan hukum (rechtspersoon). Salah . satu badan pemerintahan yang berstatus badan hukum adalah Negara. ${ }^{18}$ Negara dalam melakukan perbuatan keperdataan (kontrak) dilakukan oleh Pemerintah. Kedudukan pemerintah di sini semacam dengan kedudukan Direksi dalam sebuah Perseroan Terbatas.

Pemerintah baik secara langsung (Pemerintah Pusat, Pemerintah Daerah Provinsi dan Daerah Kabupaten/Kota), maupun secara tidak langsung (melalui BUMN, Perusahaan Negara) dapat

${ }^{17}$ Bagir Manan. 1996. "Bentuk-bentuk Perbuatan Keperdataan yang Dapat dilakukan oleh Pemerintah Daerah" Journal of Padjadjaran University. Bandung. Nomor 3 vol.14. HIm. 24.

18/bid. Him. 28. 
mengadakan perjanjian/kontrak. Di samping itu pemerintah juga dapat melakukan kontrak yang diwarnai oleh hukum publik. Kontrakyang demikian berorientasi kepada kepentingan umum dan bersifat memáksa. Di dalam kontrak yang demikian tidak terdapat kebebasan berkontrak, ${ }^{19}$ karena syarat-syarat yang ditentukan dalam kontrak itu tidak didasarkan kepada kehendak kedua belah pihak, akan tetapi hanya didasarkan kepada kehendak satu pihak yaitu Pemerintah.

Syarat-syarat tersebut ditentukan oleh perangkat peraturan perundang-undangan. Hubungan antara pemerintah dan mitranya atau (lawan kontraknya) tidak berada di dalam kedudukan yang sama (nebengeordnet), tetapi Pemerintah mempunyai kedudükan yang lebih tinggi dari mitranya (untergeordnet). Karena itu perjanjian ini disebut perjanjian publik. ${ }^{20}$

Dari kedua pendapat di atas terdapat perbedaan dalam memandang keterlibatan Pemerintah dalam berkontrak. Bagir Manan memandang hubungan antara Pemerintah dan lawan kontraknya sebagai hubungan kesederajatan. Mariam Darus Badrulzaman memandang kedudukan Pemerintah lebih tinggi (tidak sederajat) dengan lawan kontraknya. Berbeda dari kedua pendapat tersebut Sunaryati Hartono, ${ }^{21}$ memandang hubungan antara Pemerintah dan lawan kontraknya (dalam joint venture) kadang sebagai pihak (partner) dan juga sebagai Pemerintah. Oleh karena itu, kontrak yang melahirkan suatu joint venture di mana Pemerintah sebagai pihak (partner) tidak dapat dikatakan suatu perjanjian perdata atau commercial contract yang biasa. Sebab dalam kontrak yang serupa itu, Pemerintah mempunyai kedudukan rangkap baik sebagai pihak maupun sebagai Pemerintah. ${ }^{22}$

Akibatnya terhadap kontrak yang demikian, tidak hanya berlaku peraturan hukum perjanjian dan perseroan Indonesia saja, tetapi juga karena Pemerintah telah menyetujui sejumlah perjanjian bilateral dan multilateral di bidang perekonomian dengan berbagai negara dan organisasi internasional, maka kontrak dalam rangka PMA berlaku juga perjanjian-perjanjian tersebut dan peraturan Hukum Internasional. Karena itu kontrak dalam rangka PMA dinamakan perjanjian transnasional atau perjanjian quasi intemasional, contract sui generis atau economic development contract. ${ }^{23}$

Lalu bagaimana status pemerintah dalam kontrak karya? Kontrak karya bukanlah perjanjian yang dikualifikasikan sebagai perjanjian publik, melainkan perjanjian biasa yang tunduk kepada ketentuan hukum perdata. Meskipun format kontraknya bersifat, standar, namun tetap terbuka kesempatan kepada

${ }^{19}$ Lihat Pasal 1338 KUHPerdata.

${ }^{20}$ Mariam Darus Badrulzaman. "Perjanjian dengan Pemerintah (Government Contract)." Dalam Peter Mahmud Marzuki et al. (Editor). 1998. Hukum Kontrak di Indonesia. Jakarta: ELIPS. HIm. 159.

${ }^{21}$ Sunaryati Hartono. 1974. Masalah-Masalah Dalam Joint Ventures Antara Modal Asing Indonesia. Bandung:Alumni. HIm. 28.

${ }^{22}$ Ibid.

${ }^{23} \mathrm{lbid}$. Him. 29. 
kontraktor untuk merundingkan semua ketentuan-ketenuan yang dimuat dalam format kontrak. ${ }^{24}$ Hubungan pemerintah dengan kontraktor dalam kontrak karya adalah hubungan kontraktual. Hubungan kontraktual dapat dipahami bahwa kedua subjek hukum yang melakukan perbuatan perdata itu mempunyai kedudukan yang sama yaitu sebagai para pihak tanpa memandang status diluar kontrak.

Suatu catatan yang perlu diingat bahwa manakala badan pemerintah mengadakan kontrak (menggunakan hukum perdata) dengan warga masyarakat atau badan hukum, maka menurut asas dalam hukum perdata; ia dianggap berkedudukan sejajar dengan lawan kontraknya (staat op gelijke voet als een privaat persoon). ${ }^{25}$ Hubungan kesederajatan itu merupakan jaminan bahwa kedudukan badan pemerintahan yang bersangkutan tidak dalam kedudukan yang diistimewakan, baik pada penyusunan maupun pada pelaksanaan kontrak karya.

Meskipun anggapan yuridis tersebut tidak realistis, sebab dalam kenyataannya dalam tindakan apapun yang dilakukan pemerintah, ia tidak dapat melepaskan diri sebagai penjaga dan pemelihara kepentingan umum. Oleh karena, itu walaupun pemerintah menggunakan hukum perdata, tidak boleh dilupakan bahwa ketentuan-ketentuan hukum publik yang berlaku harus tetap diperhatikan pula.
Pendapat yang demikian kurang tepat, sebab tindakan pemerintah dalam kapasitasnya sebagai pihak yang mewakili negara, tidak bisa membawa statusnya sebagai Pemerintah yang dapat melakukan tindakan menurut ketentuan hukum publik (misalnya memberikan Kuasa Pertambangan). Betapapun sulitnya dipisahkan status pemerintah (negara) sebagai pihak dan status Pemerintah selaku penguasa yang tunduk kepada ketentuan hukum publik, namun tetap dapat dibedakan kapan ia seharusnya bertindak sebagai pihak dan kapan sebagai pemerintah. Bahkan dalam setiap naskah kontrak karya terdapat ketentuan yang mengatur hak-hak khusus Pemerintah.

Dalam kontrak karya, Menteri Pertambangan dan Energi bertindak untuk dan atas nama Pemerintah Republik Indonesia selaku prinsipal. Pertanyaan: "Bagaimanakah jika terjadi sengketa para pihak? Dalam setiap naskah kontrak karya terdapat ketentuan bahwa jika terjadi sengketa, para pihak dapat menyelesaikannya dengan melalui dua cara; Pertama, konsiliasi (berdamai), sebagaimana ketentuan dalam peraturan konsiliasi United Nations Commision on Intemational Trade Law (UNCITRAL) yang termuat dalam Resolusi 351 52 Majelis Umum Perserikatan BangsaBangsa (PBB) tanggal 4 Desember 1980; Kedua, melalui arbitrase (peradilan perwasitan) sebagaimana ketentuan dalam peraturan Arbitrase UNCITRAL (Resolusi 31/

\footnotetext{
${ }^{24}$ Karena semua ketentuan-ketentuan dalam kontrak karya dapat dirundingkan dengan Pemerintah, maka setiap kontrak karya memiliki kekhususan yang menjadi ciri untuk setiap generasi kontrak karya.

${ }^{25}$ indroharto. 1994. Peradilan Tata Usaha Negara. Buku I (Edisi Baru). Jakarta: Pustaka Sinar Harapan. HIm. 18
} 
98 Majelis Umum PBB tanggal 15 Desember 1976. ${ }^{26}$ Tempat acara konsiliasi atau arbitrase akan dilakukan di Jakarta, kecuali para pihak menentukan lain atau tata cara tersebut menghendaki lain. Berdasarkan cara-cara penyelesaian tersebut, menunjukkan bahwa pemerintah tidak dapat melakukan tindakan sepihak, melainkan atas kesepakatan atau berdasarkan putusan pihak ketiga baik secara yustisial maupun non-yustisial.

Dengan demikian, kedudukan pemerintah sebagai para pihak dalam sengketa, sangat tidak menguntungkan, sebab pemerintah adalah organ negara dan pelaksana hak penguasaan negara. Pemerintah selaku pemberi kuasa pertambangan (Pasal 10 UUPP 1967) yang apabila terjadi sengketa, seharusnya bertindak sebagai wasit untuk menyelesaikan sengketa, bukan sebagai pemain yang dapat dikalahkan oleh pihak lain sebab akan membawa kerugian bagi negara dan mengurangi wibawa pemerintah sendiri. Kedudukan yang demikian sangat dillematis.

\section{(2) Kontrak Production Sharing (production sharing contract)}

\section{a. Pengertian dan Dasar Hukum}

Pola production sharing Contract dipakai khusus dalam usaha pertambangan minyak dan gas bumi. Bentuk kontrak ditetapkan dalam ketentuan Pasal 12 ayat (1) Undangundang Nomor 8 Tahun 1971. ${ }^{27}$ Pengertian kontrak bagi hasil adalah kontrak/perjanjian kerjasama antara Pertamina dan Perusahaan Asing (selaku kontraktor) untuk melaksanakan usaha eksplorasi dan eksploitasi bahan galian minyak dan gas bumi berdasarkan prinsip pembagian hasil produksi (share). Dasar hukum pola ini ialah Pasal 6 ayat (1) UndangUnidang Nomor 44 Prp. Tahun $1960^{28}$ jo Pasal 10 ayat (1) UUPP 1967 dan Undang-Undang Nomor 8 Tahun 1971. Meskipun kedua undang-undang yang disebut pertama dị atas disebut sebagai dasar hukum kontrak production sharing, namun di dalamnya tidak disebutkan kontrak production sharing,

${ }^{2}$ Suatu perangkat peraturan bersama dalam peradilan perwasitan. UNCITRAL adalah sebuah Komisi yang diasosiasikan dengan Perserikatan Bangsa-Bangsa dan bertanggungjawab dalam pengembangan hukum. Dagang Internasional. Di samping itu disediakan untuk memberikan jasa arbitrase pada bisnis internasional; John W. Head. 1997. Pengantar Hukum Ekonomi. Jakarta: ELIPS. HIm. 80.

${ }^{27}$ Pasal 12 ayat (1) selengkapnya berbunyi: Perusahaan dapat mengadakan kerjasama dengan pihak lain dalam bentuk Kontrak Production Sharing.

${ }^{28}$ Pasal 6 ayat (1) selengkapnya berbunyi:

(1) Menteridapat menunjuk pihak lain sebagai kontraktor untuk Perusahaan Negara apabila diperlukan untuk melaksanakan pekerjaan-pekeriaan yang belum atau tidak dapat dilaksanakan sendiri oleh Perusahaan Negara yang bersangkutan selaku Pemegang Kuasa Pertambangan.

(2) Dalam mengadakan perjanjian karya dengan kontraktor sepert yang dimaksud dalam ayat (1) di atas Perusahaan Negara harus berpegang pada pedoman-pedoman, petunjuk-petunjuk dan syarat-syarat yang diberikan oleh Menteri. 
melainkan istilah perjanjian karya, sedangkan istilah kontrak bagi hasil sendiri terdapat dalam ketentuan Pasal 12 Undang-undang Nomor 8 Tahun 1971.

Pola perjanjian karya pada pengusahaan pertambangan minyak dan gas bumi digunakan hingga tahun 1964, sebelum diganti dengan pola production sharing. Kedua pola kerjasama ini di dalamnya terdapat perbedaan yang sangat prinsipil dari sisi yuridis yaitu pengalihan manajemen pengusahaan dari kontraktor kepada
Pertamina. Dengan kewenangan manajemen pengusahaan pada pihak Pertamina sesungguhnya bukan pengalihan, melainkan pengembalian proporsi yang seharusnya memang demikian. Sebab Pertamina dalam kontrak, statusnya sebagai pemegang kuasa pertambangan yang diberikan wewenang untuk melakukan pengusahaan pertambangan minyak dan dan gas bumi. Selain pengembalian manajemen, masih terdapat perbedaan lain antara keduanya sebagaimana dirinci dalam Tabel 1. di bawah ini.

Tabel 1

Perbandingan Antara Perjanjian Karya
dengan Kontrak Production Sharing

\begin{tabular}{|c|c|c|c|}
\hline $\begin{array}{l}\text { No. } \\
\text { Urut }\end{array}$ & Perihal & Perjanjian Karya & $\begin{array}{l}\text { Kontak Production } \\
\text { Sharing }\end{array}$ \\
\hline 1 & Dasar Hukum & UU No. 44.Prp/1960 UU No. 14/1963 & $\begin{array}{l}\text { UU No. } 44 \text { Prp/1960 } \\
\text { UU No. } 8 / 1971\end{array}$ \\
\hline 2 & Keadaan Kontrak & $\begin{array}{c}\text { Perjanjian Karya diratifikasi DPR menjadi } \\
\text { Undang-undang }\end{array}$ & $\begin{array}{c}\text { Kontrak antara } \\
\text { Pertaminadan Kontraktor }\end{array}$ \\
\hline 3 & Mulai Berlaku oleh & Disyahkan dengan UU & DisetujuiPresiden \\
\hline 4 & Masa Berlaku & Old Area 20 Tahun NewArea 30 Tahun & 30Tahun \\
\hline 5 & Kewenangan Manajemen & Kontraktor & Pertamina \\
\hline 6 & $\begin{array}{c}\text { Dasar Pembagian } \\
\text { Keuntungan }\end{array}$ & Hasil Penjualan Migas & Migas yang Diproduksi \\
\hline 7 & $\begin{array}{c}\text { Peralihan Hak } \\
\text { Pemilikan atas Migas }\end{array}$ & Beralih pada "POINT OF SALE' & $\begin{array}{l}\text { Beralihpada } \\
\text { "POINT OF EXPORT" }\end{array}$ \\
\hline 8 & Pemilikan Atas Perlengkapan & Kontraktor & $\begin{array}{c}\text { Pertamina berhak atas } \\
\text { perlengkapan untuk operasi }\end{array}$ \\
\hline
\end{tabular}




\section{b. Para Pihak dalam Kontrak Production Sharing}

Sesuai dengan ketentuan Pasal 6 ayat (1) Undang-undang Nomor 44 Prp. Tahun 1960 secara tegas menyebutkan bahwa Menteri dapat menunjuk pihak lain sebagai kontraktor untuk perusahaan' negara (saat ini adalah PERTAMINA) apabila diperlukan untuk melaksanakan pekerjaan-pekerjaan yang belum atau tidak dapat dilakukan sendiri oleh Pertamina sebagai pemegang kuasa pertambangan. ${ }^{29}$

Kemudian ketentuan Pasal 10 ayat (1) UUUPP 1967 pada prinsipnya säma dengan ketentuan Pasal 6 Undang-undang Nomor 44 Prp. Tahun 1960 di atas. Dari ketentuan kedua undang-undang tersebut dapat ditarik kesimpulan bahwa yang menjadi prinsipal atau pihak dalam kontrak adalah Perusahaan Negara. Oleh karena Pertamina sebagai prinsipalnya, maka kedudukan Pemerintah berada di atas para pihak (Pertamina dan kontráktor). Lalu bagaimana jika terjadi sengketa? Apabila tejadi sengketa atau konflik antara para pihak dalam pola Kontrak Production Sharing ini, maka diselesaikan menurut ketentuan Pasal 11 setiap naskah kontrak production sharing melalui cara: .

1. Pertamina dan kontraktor akan memusyawarahkan berbagai masalah sehubungan dengan dilaksanakannya kontrak, biasanya melalui bimbingan Direktur Jenderal Minyak dan Gas Bumi selaku Pemerintah (angka 1);

2. Apabila sengketa yang timbul tidak dapat diselesaikan melalui musyawarah dengan bimbingan Dirjen Migas (pada point 1), maka sengketa tersebut.akan diputuskan melalui arbitrase dengan menggunakan tatacara regulasi dari Intemational Chamber of Commerce (ICC), (angka 1.2);

3. Apabila para arbitrator tidak dapat mencapai keputusan (pada point 2), maka sengketa tersebut akan dibawa dan diselesaikan pada Pengadilan Negeri di Jakarta.

Bertolak dari cara-cara penyelesaian di atas jika terjadi sengketa para pihák, maka pada pola kontrak production sharing. kedudukan pemerintah sangat kuat, karena berada di atas para pihak. Kedudukan yang demikian, Pemerintah memposisikan diri sebagai pembimbing atau pengawas yang dapat mencegah timbulnya sengketa. Kalaupun terjadi sengketa; Pemerintah dapat menjadi mediator atau wasit sebelum sengketa para pihak itu di bawa ke Arbitrator. Selanjutnya, pemerintah merupakan pintu terakhir dalam penyelesaian sengketa jika para arbitrator tidak dapat mencapai kesepakatan dalam upaya penyelesaian sengketa. Pintu terakhir itu melalui. Pengadilan Negeri di Jakarta.

\footnotetext{
${ }^{22}$ Usaha pertambangan minyak dan gas bumi adalahi mónopoli Pertamina atau pemegang kuasa pertambangan satu-satunya:

(1) Pasal 3 ayat (2) Undang-undang Nomor 44 Prp. Tahun 1960 yang berbunyi: " Usaha pertambangan minyak dan gas bumi dilaksanakan oleh Perusahaan Negara semata-mata"

(2) Penjelasan umum angka 5 Undang-undang Nomor 44 Prp. Tahun 1960 yang menyebutkan bahwa hanya Perusahaan Negaralah yang dapat menguasaisuatu wilayah pertambangan minyak dan gas bumi dan hak inipun jauh berlainan dengan konsesi yang lama".
} 
(3) Perjanjian Karya Pengusahaan Pertambangan Batubara (Coal Agreement)

\section{a. Pengertian dan Dasar Hukum}

Pola Perjanjian Karya Pengusahaan Pertambangan Batubara (Coal Agreement) merupakan pola campuran (mixed) antara pola kontrak karya dan kontrak production sharing. Dikatakan campuran karena untuk ketentuan-ketentuan perpajakan mengikuti pola kontrak karya sedangkan pembagian hasil (production share) sebagai royalti mengikuti pola production sharing contract. Pemerintah Indonesia menerima royalti sebesar $13,5 \%$ dari produksi kotor.

Pengertian Perjanjian Karya Pengusahaan Pertambangan Batubara ialah perjanjian antara Pemerintah dengan Perusahaan kontraktor swasta nasional/asing untuk melaksanakan pengusahaan pertambangan bahan galian batubara. Dasar hukum pola Perjanjian Karya Pengusahaan Pertambangan Batubara, juga mengacu kepada Pasal 10 ayat (1) UUPP 1967 jo Pasal 8 Undang-undang Nomor 1 Tahun 1967 dan Keputusan Presiden Nomor 75 Tahun 1996 tentang Ketentuan Pokok Perjanjian Karya Pengusahaan Pertambangan Batubara.

\section{b. Para Pihak dan Penyelesaian Sengketa}

Pola Perjanjian Karya Pengusahaan Pertambangan Batubara semula yang menjadi prinsipalnya adalah PT. Tambang Batubara Bukit Asam yang merupakan BUMN satusatunya pemegang Kuasa Pertambangan untuk pengusahaan bahan galian batu-bara, namun setelah dikeluarkannya Keputusan Presiden Nomor 75 Tahun 1996 yang menjadi prinsipal bukan lagi PT. Tambang Batubara Bukit Asam melainkan Pemerintah Republik Indonesia yang diwakili oleh Menteri Pertambangan dan Energi. Berdasarkan ketentuan tersebut Perjanjian Karya Pengusahaan Pertambangan Batubara saat ini lebih populer dengan sebutan Kontrak Karya Batubara. Dengan demikian para pihak dalam kontrak karya batubara adalah; (1) Pemerintah Republik Indonesia dan; (2) Perusahaan swasta nasional/asing yang telah berbadan hukum Indonesia serta berkedudukan di Indonesia sebagai kontraktor. Kontraktor pada kontrak karya batubara, selain kontraktor asing, juga dimungkinkan keterlibatan badan usaha swasta nasional (kontraktor nasional).

Apabila terjadi sengketa antara kedua belah pihak, mereka sepakat untuk menyelesaikan semua sengketa, baik yang tejadi sebelum ataupun sesudah pengakhiran perjanjian melalui; konsiliasi dan badan arbitrase. Dalam hal kedua belah pihak hendak mencari penyelesaian secara damai atas sengketa melalui cara konsiliasi, maka bagi kontraktor asing, konsiliasi dilakukan sesuai dengan Peraturan Konsiliasi dari United $\mathrm{Na}$ tions Commision on International Trade Law (UNCITRAL) yang terdapat dalam Resolusi $35 /$ 52 Majelis Umum PBB tanggal 4 Desember 1980. Bagi kontraktor nasional, konsiliasi dilakukan sesuai dengan peraturan konsiliasi yang dianut oleh Badan Arbitarse Nasional Indonesia (BANI). Dalam hal kedua belah pihak hendak berarbitrase, bagi kontraktor asing, sengketa akan diselesaikan dengan arbitrase berdasarkan Peraturan Arbitrase UNCITRAL yang terdapat dalam Resolusi 31/98 Majelis Umum PBB $31 / 98$ tanggal 15 Desember 1976, sedangkan bagi kontraktor nasional, sengketa akan diselesaikan dengan arbitrase berdasarkan 
peraturan arbitrase BANI. Tempat acara konsiliasi atau: arbitrase akan dilakukan di Jakarta, kecuali para pihak menentukan lain 'atau tata cara tèrsebut menghendaki lain.

.. Keputusan arbitrase mengikat keduä belah pihak dan harus dapat dilaksanakan. Kontrak yang salah sätu pihakñya adalah kontraktor asing secara khusus keputusan tersebut harus dilaksanakan di Indonesia tanpa memandang apakah acaranya dilangsungkan di Indonesia atau tidak.

\section{'Analisis Perbandingañ dari Ketiga Pola Kontrak' Kerjasama}

(1) Dari segi istilah; kontrak karya sesuai dengan Pasal 8 ayat (1) UU PMA, Kontrak. Production Sharing sesuai dengan Pasal 12 ayat (1) UU Nomor 8 Tahun 1971 dan Perjanjian Karya Pengusahaan Pertambangan Batubara sesuai dengan Keputusan Presiden Nomor 75 Tahun 1996, sedangkan penggunaan istilah perjanjian karya dalam UUPP. 1967 dan UU Nomor 44 Prp. Tahun 1960 dimakssudkan untuk perjanjian kerjasama antara pemegang kuasa pertambangan dengan pihak lain (kontraktor), bukan untuk perjanjian kerjasama antara pemerintah dengan kontraktor asing.

(2) Dari segi prinsipal; pada pola kontrak karya dan perjanjian karya pengusahaan pertambangan batubara, Pemerintah Republik Indonesia sebagai prinsipalnya dan pada pola kontrak production sharing yang menjadi principal adalah Pertamina. Pada setiap perjanjian kerjasama pengusahaan pertambangan jika prinsipalnya adalah Pemerintah RI, maka sebelum disetujui oleh Presiden terlebih dahulu dikonsultasikan dengan Dewan Perwakilan Rakyat. Kècuali apabila salah satu pihak dalam perjanjian/kontrak yang bersangkutan adalah kontraktor nasional (PMDN):

(3) Dari segi kewenangan manajemen; pada pola kontrak karya dan Perjanjiannya Pengusahaan Pertambangan Batubara manajemen pengusahaan ada padá pihak kontraktor, sedangkan pada pola kontrak production sharing, kewenangan manajemen adda pada Pertamina.

(4) Dari segi penerimaan negara; pada pola kontrak karya penerimaan negara dari royalti, iuran tetap dan berbagai jenis pajak, sedangkan pada pola kontrak production sharing, negara mendapat bagian $85 \%$ dari seluruh produksi dan beberapa jenis pajak, sementara pada pola perjanjian karya pengusahaan pertambangan batubara, penerimaan negara dari royalti $13,5 \%$ dari seluruh produksi dan beberapa jenis pajak.

Selain dari keempat hal tersebut di atas, masih terdapat beberapa perbedaan antara ketiga ,pola . kerjasama pengusahaan pertambangan itu. Untuk lebih jelasnya, Penulis akan menyajikan pada Tabel 2 di bawah ini: 
Tabel 2

Perbandingan Tiga Pola Kerjasama Pengusahaan Pertambangan

\begin{tabular}{|c|c|c|c|c|}
\hline \multirow{2}{*}{$\begin{array}{l}\text { No. } \\
\text { Urut }\end{array}$} & \multirow{2}{*}{ Perihal } & \multicolumn{3}{|c|}{ Pola Kerjasama Pengusahaan Pertambangan } \\
\hline & & KK & KPS & PKP2B \\
\hline 1 & Dasar Hukum & $\begin{array}{l}\text { Ps. } 10 \text { UUPP } 1967 \\
\text { Ps. } 8 \text { UU PMA }\end{array}$ & $\begin{array}{l}\text { Ps. } 6 \text { UU MGAS } \\
\text { Ps. } 12 \text { UU } 8 / 71\end{array}$ & $\begin{array}{l}\text { Ps. } 10 \text { UUPP } 1967 \\
\text { Kepres 75/96. }\end{array}$ \\
\hline 2 & Keadaan Kontrak & $\begin{array}{l}\text { Dikonsultasikan DPR dan } \\
\text { BKPM sebelum disetujui } \\
\text { Presiden }\end{array}$ & Persetujuan Presiden & $\begin{array}{l}\text { Dikonsultasikan DPR dan } \\
\text { BKPM untuk PMA dan } \\
\text { PMDN hanya BPKM } \\
\text { sebelum disetujuipresiden. }\end{array}$ \\
\hline 3 & Para Pihak & $\begin{array}{l}\text { Pemerintah Kontraktor } \\
\text { Asing }\end{array}$ & $\begin{array}{l}\text { Pemerintah Kontraktor } \\
\text { Asing }\end{array}$ & $\begin{array}{l}\text { Pemerintah Kontraktor Asing } \\
\text { dan Nasional }\end{array}$ \\
\hline 4 & Mulai Berlaku & $\begin{array}{l}\text { Setelah Ditanda tangani } \\
\text { parapihak }\end{array}$ & Setelah disetujui Presiden & $\begin{array}{l}\text { Setelah ditandatangani para } \\
\text { pihak }\end{array}$ \\
\hline 5 & Masa Berlaku & 30 tahun sejak produksi & 30 tahun & 30Tahun sejakmasaproduksi \\
\hline 6 & Kewenangan & Kontraktor Manajemen & Pertamina & Kontraktor \\
\hline 7 & Peralihan Hak & $\begin{array}{l}\text { Setelah Melunasi Royalti } \\
\text { dan memenuhi kewajiban } \\
\text { lain. }\end{array}$ & $\begin{array}{l}\text { Point of export (85:15)\% } \\
\text { untuk Minyak dan (70:30) } \\
\text { untuk Gas. }\end{array}$ & $\begin{array}{l}\text { Setelah Perlunasan Royalti } \\
13,5 \% \text { at sale point. }\end{array}$ \\
\hline 8 & Dasar Pembagian & Hasil Penjualan Produksi & $\begin{array}{l}\text { Migas yang diproduksi } \\
\text { (Natura) }\end{array}$ & $\begin{array}{l}\text { Batubara yang diproduksi tapi } \\
\text { dalam perkembangan hasil } \\
\text { penjualannya. }\end{array}$ \\
\hline
\end{tabular}

Keterangan: $\mathrm{KK}=$ Kontrak Karya, KPS= Kontrak Production sharing $\mathrm{PKP} 2 \mathrm{~B}=$ Perjanjian Karya Pengusahaan Pertambangan Batubara 


\section{Simpulan}

Berdasarkan analisis perbandingan ketiga pola kontrak kerjasama di atas, maka dapat disimpulkan:

(1) Terdapat dua pola hubungan hukum pemerintah dengan badan usaha swasta dalam usaha pertambangan: Pertama, hubungan hukum yang didasarkan pada status pemerintah sebagai pelaksana hak penguasaan negara. Kedua, hubungan hukum yang didasarkan pada kontrak atau hubungan kontraktual (kesederajatan).

(2) Di dalam pola Production Sharing Contract di sektor pertambangan minyak dan Gas Bumi hubungan pemerintah déngan badan usaha swasta (kontraktor) didasarkan pada status pemerintah sebagai pelaksana hak penguasaan negara.

(3) Pada pola Mining Contract of Work dan Coal Agreement di sektor pertambangan umum hubungan pemerintah dengan badan usaha swasta didasarkan pada hubungan kontraktual( kesederajatan).

\section{Daftar Pustaka}

Friedmann, W. 1966. Legal Theory. London: Steven \& Sons.

- 1971. The State and The Rule of Law in A Mixed Economy. London: Steven \& Sons.

Gie, Kwik Kian. "Siapa yang Punya Kekayaan Alam Indonesia? (artikel)" Harian Umum Kompas, Jakarta 20 Februari 1997.
- "Mitos Soal Badan Usaha Milik Negara." Harian Kompas. Jakarta, 3 Pebruari 1997.

Hartono, Sunaryati. 1974. Masalah-masalah Dalam Joint Ventures antara Modal Asing dan Modal Indonesia. Bandung: Alumni.

John, Head, W. 1997. Pengantar Hukum Ekonomi, Edisi Bahasa Indonesia dan Inggeris. Jakarta: ELIPS.

Kamelus, Deno. 1998. Fungsi Hukum Terhadap Ekonomi di Indonesia. PPs: Surabaya: UNAIR.

Marian, Bagir. "Bentuk-bentuk Perbuatan Keperdataan yang Dapat Dilakukan oleh Pemerintah Daerah, (artikel)." Journal of Padjadjaran University. LP-UNPAD, Bandung, Nomor 3 Vol. 14 Th. 1996

Marzuki, Peter Mahmud et. al. (editor). 1998. Hukum Kontrak di Indonesia. Jakarta: ELIPS.

Pertamian-BPPKA. 1998. Sejarah Perkembangan Production Sharing Contract. Jakarta.

Subekti. 1983. Pokok-pokok Hukum Perjanjian. Jakarta: Intermasa.

1984. Pokok-pokok Hukum Perdata. Jakarta: Intermasa.

Sigit,Soetarjo. 1996. "Potensi Sumber Daya Mineral dan Kebangkitan Pertambangan Indonesia." Pidato Ilmiah pada Penganugrahan Gelar Doktor Honoris Causa. Bandung: ITB. 
-_. "Analisis Kebijakan Sektor Pertambangan Indonesia." Makalah Jurusan Teknik Pertambangan Umum .FTM-ITB, Bandung, 27 September 1997.

. dan S. Yudonarpodo. 1993. "Legal Aspects of The Mineral Industry in Indonesia." (Makalah). Jakarta: Indonesian Mining Association (IMA).

Turpin, Colin. 1972. Government Contract. London: Penguin Book Ringwood.

Departemen Pendidikan dan Kebudayaan \& Balai Pustaka. 1995. Kamus Besar Bahasa Indonesia. (edisi kedua). Jakarta.
Undang-Undang Nomor 44 Prp Tahun 1960 tentang Pertambangan Minyak dan Gas Bumi (LN. Tahun 1960 Nomor 133).

Undang-Undang Nomor 1 Tahun 1967 tentang Penanaman Modal Asing (LN Tahun 1967 Nomor 1).

Undang-Undang Nomor 11 Tahun 1967 tentang Ketentuan-ketentuan Pokok Pertambangan (LN Tahun 1967 Nomor 22).

Undang-Undang Nomor 8 Tahun 1971 tentang Perusahaan Pertambangan Minyak dan Gas Bumi Negara (LN Tahun 1971 Nomor 76).

Keputusan Presiden Nomor 75 Tahun 1996 tentang Pejanjian Kanya Pengusahaan Pertambangan Batubara.

中ぬ妨 